\title{
Study of Impact of Serum Uric Acid in Type 2 Diabetic Patients And Its Relationship with Development of Complications
}

\author{
Maniappan ${ }^{1,}$ Manshur $^{2}$, Uvaraj muruganandam $^{2}$ \\ ${ }^{1}$ Associate Professor Of Medicine, Dept. Of Internal Medicine, Coimbatore Medical College Hospital, \\ Coimbatore, Tamilnadu, India. \\ ${ }^{2}$ Assistant Professor Of Medicine, Dept. Of Internal Medicine, Coimbatore Medical College Hospital, \\ Coimbatore, Tamilnadu, India.
}

\begin{abstract}
Background: Diabetes Mellitus is a leading health problem with increasing incidence and associated with cardiovascular, renal, neurological complications etc. Elevated serum uric acid plays an important risk factor for the development of cardiovascular, renal, ophthalmological, neurological and metabolic disturbance. Elevated levels of serum uric acid in type 2 DM increases risk of developing all complications especially chronic kidney disease.

Aim and Objectives: To study the impacts of serum uric acid in type 2 diabetes mellitus, and its relation with development of complications.

Material and methods: Cross sectional observational study.

Results and conclusion: Elevated level of serum uric acid level in type 2 DM correlates with its complications.

Keywords: Diabetes mellitus, complications, serum uric acid.
\end{abstract}

\section{Introduction}

World Health Organization (WHO), defines the term Diabetes Mellitus (DM) as a metabolic disorder of multiple etiology, characterized by chronic hyperglycemia with disturbances of carbohydrate, protein and fat metabolism, resulting from defects in insulin secretion or insulin action or both ${ }^{[1] .}$ Diabetes mellitus is a leading public health problem with increasing incidence and long term complications such as diabetic nephropathy, diabetic neuropathy, diabetic retinopathy etc. These complications are mainly a consequence of macro vascular and micro vascular damages of the target organs. According to WHO, the prevalence of Diabetes Mellitus has reached epidemic proportions. The total number of people worldwide with diabetes is projected to rise from 150 million in 2000 to 435 million in 2030. The top three countries are India, China and U.S. India is called Diabetic Capital of World as there are going to be eighty percent of all diabetics from the entire world population, concentrated here ${ }^{[2] .}$ In 2000 the number of people with diabetes was 31.7 million and it is expected that by 2030 this will increase to 79.4 million ${ }^{[3]}$.There is one person in the world dying of diabetes every ten seconds and new diabetic cases being identified every ten seconds. The worst affected are people in the age group of 40 to 59 years ${ }^{[2] . ~ S e v e r a l ~ f a c t o r s ~ c o n t r i b u t i n g ~ t o ~ t h i s ~ i n c l u d e ~ g r e a t e r ~ l o n g e v i t y, ~ o b e s i t y, ~ u n s a t i s f a c t o r y ~ d i e t, ~}$ sedentary lifestyle and increasing urbanization. The cause of clinical diabetes is absolute or relative deficiency of insulin. Type1 or IDDM is due to insulin deficiency caused by autoimmune destruction of B cells in the islets of pancreas, the A, D and F cells remain intact ${ }^{[4]}$. The second form of diabetes mellitus is Type 2 or NIDDM, is characterized by insulin resistance and impaired insulin receptors. It is common type of diabetes and usually develops after the age of 40 years. It is associated with normal B cell morphology ${ }^{[4]}$. Type 2 diabetes comprises $90 \%$ of people with diabetes all around the world, and is largely the result of excess body weight and physical inactivity

\section{Materials And Methods:}

This is a cross sectional observational study conducted in coimbatore medical college hospital, Coimbatore over the period of one year. The Ethics committee clearance was obtained.100 Diabetic Patients attending the outpatient department of medicine who are willing to participate in the study were included. Patients excluded were pregnant ladies, patients on xanthine Oxidase inhibitors or uricosuric drugs, thiazides, salicylates OC pills, Cytotoxic drugs and lipid lowering agents, Patients with Lymphoma, Leukemia organ transplant recipients, Alcoholics, smokers and Nephrotic syndrome patients.

\section{Result}

Table 1showing age and sex distribution among the study population. A total of 100 patients were studied of whom 59 were male and 41 were female. Most of the patient came under the age of 41-50 years of 
age and the number was 34 . In total study population 50 patient showed elevated serum uric acid. Among them 29 patients were male and 21 were female.

Table No 1

Age and sex distribution of the subjects studied

\begin{tabular}{|l|l|l|l|}
\hline $\begin{array}{l}\text { Age groups } \\
\text { (Yrs) }\end{array}$ & Male & Female & total \\
\hline $31-40$ & $\mathbf{1 4}$ & $\mathbf{0 6}$ & $\mathbf{2 0}$ \\
\hline $41-50$ & $\mathbf{2 0}$ & $\mathbf{1 4}$ & $\mathbf{3 4}$ \\
\hline $51-60$ & $\mathbf{1 0}$ & $\mathbf{0 8}$ & $\mathbf{1 8}$ \\
\hline $61-70$ & $\mathbf{0 7}$ & $\mathbf{0 6}$ & $\mathbf{1 3}$ \\
\hline $71-80$ & $\mathbf{0 6}$ & $\mathbf{0 5}$ & $\mathbf{1 1}$ \\
\hline $81-90$ & $\mathbf{0 3}$ & $\mathbf{0 1}$ & $\mathbf{0 4}$ \\
\hline
\end{tabular}

Table 2 represents the association between ECG changes and serum uric acid levels and we found that 75 study population showed ecg changes among them 42 patient had elevated serum uric acid and value were statistically significant ( $\mathrm{P}$ value - 0.038). from this table we observed that diabetic patients with elevated serum uric acid were showed ECG changes than normal value.

Table No 2

ECG changes and serum uric acid level in the study subjects

\begin{tabular}{|c|c|c|c|c|c|c|}
\hline & & & \multicolumn{2}{|c|}{ Serum uric acid } & \multirow{2}{*}{ Total } & \multirow[t]{2}{*}{$\mathrm{P}$ value } \\
\hline & & & high & low & & \\
\hline \multirow[t]{4}{*}{$\begin{array}{l}\text { ECG } \\
\text { changes }\end{array}$} & \multirow{2}{*}{ present } & Count in & 42 & 33 & 75 & \multirow{6}{*}{0.038} \\
\hline & & $\%$ of Total & $42.0 \%$ & $33.0 \%$ & $75.0 \%$ & \\
\hline & absent & Count in & 8 & 17 & 25 & \\
\hline & & $\%$ of Total & $8.0 \%$ & $17.0 \%$ & $25.0 \%$ & \\
\hline \multirow{2}{*}{ Total } & & Count in & 50 & 50 & 100 & \\
\hline & & $\%$ of Total & $50.0 \%$ & $50.0 \%$ & $100.0 \%$ & \\
\hline
\end{tabular}

Table 3 represents the association between usg changes and serum uric acid level in study in population and the reports shows that 46 patient showed abnormal usg abdomen finding of whom 29 patients showed elevated serum uric acid value and the value were statistically significant with the p value of 0.016 .

Table No.3

USG changes in study subjects associated with serum uric acid level

\begin{tabular}{|c|c|c|c|c|c|c|}
\hline & & & \multicolumn{2}{|c|}{ Serum uric acid } & \multirow{2}{*}{ Total } & \multirow[b]{2}{*}{$P$ value } \\
\hline & & & high & low & & \\
\hline \multirow[t]{4}{*}{$\begin{array}{l}\text { USG } \\
\text { changes }\end{array}$} & \multirow{2}{*}{ Present } & Count in & 29 & 17 & 46 & \\
\hline & & $\%$ of Total & $29.0 \%$ & $17.0 \%$ & $46.0 \%$ & \multirow[b]{2}{*}{0.016} \\
\hline & Absent & Count in & 21 & 33 & 54 & \\
\hline & & $\%$ of Total & $21.0 \%$ & $33.0 \%$ & $54.0 \%$ & \\
\hline \multirow{2}{*}{ Total } & & Count in & 50 & 50 & 100 & \\
\hline & & $\%$ of Total & $50.0 \%$ & $50.0 \%$ & $100.0 \%$ & \\
\hline
\end{tabular}


Study Of Impact Of Serum Uric Acid In Type 2 Diabetic Patients And Its Relationship....

Table 4 represents the association between the fundus change and the serum uric acid level. We observed that there is positive correlation between elevated serum uric acid and the fundus changes.

Table No 4

Fundus changes in study subjects associated with serum uric acid level

\begin{tabular}{|c|c|c|c|c|c|c|}
\hline & & & \multicolumn{2}{|c|}{ Serum uric acid } & \multirow{2}{*}{ Total } & \multirow[b]{2}{*}{$P$ value } \\
\hline & & & high & low & & \\
\hline \multirow[t]{4}{*}{$\begin{array}{l}\text { Fundus } \\
\text { changes }\end{array}$} & \multirow{2}{*}{ present } & Count in & 43 & 22 & 65 & \\
\hline & & $\%$ of Total & $43.0 \%$ & $22.0 \%$ & $65.0 \%$ & \\
\hline & \multirow[t]{2}{*}{ absent } & Count in & 7 & 28 & 35 & \multirow[t]{2}{*}{0.001} \\
\hline & & $\%$ of Total & $7.0 \%$ & $28.0 \%$ & $35.0 \%$ & \\
\hline \multirow{2}{*}{ Total } & & Count & 50 & 50 & 100 & \\
\hline & & $\%$ of Total & $50.0 \%$ & $50.0 \%$ & $100.0 \%$ & \\
\hline
\end{tabular}

Table 5,6 represents the association between the serum uric acid and vibration, joint, position senses changes. From the study we found that there is positive correlation between serum uric acid levels and joint, position, vibration sense.

Table No.5

Serum uric acid level in the patients with impaired vibration sense

\begin{tabular}{|c|c|c|c|c|c|c|}
\hline & & & \multicolumn{2}{|c|}{ Serum uric acid } & \multirow{2}{*}{ Total } & \\
\hline & & & high & low & & $P$ value \\
\hline \multirow[t]{4}{*}{$\begin{array}{l}\text { Impaired } \\
\text { vibration }\end{array}$} & \multirow{2}{*}{ present } & Count in & 16 & 3 & 19 & \multirow{6}{*}{0.001} \\
\hline & & $\%$ of Total & $16.0 \%$ & $3.0 \%$ & $19.0 \%$ & \\
\hline & absent & Count in & 34 & 47 & 81 & \\
\hline & & $\%$ of Total & $34.0 \%$ & $47.0 \%$ & $81.0 \%$ & \\
\hline \multirow{2}{*}{ Total } & & Count & 50 & 50 & 100 & \\
\hline & & $\%$ of Total & $50.0 \%$ & $50.0 \%$ & $100.0 \%$ & \\
\hline
\end{tabular}

Table No.6

Serum uric acid level in the patients with impaired joint position sense

\begin{tabular}{|c|c|c|c|c|c|c|}
\hline & & & \multicolumn{2}{|c|}{ Serum uric acid } & \multirow{2}{*}{ Total } & \multirow[b]{2}{*}{$P$ value } \\
\hline & & & high & low & & \\
\hline \multirow[t]{4}{*}{$\begin{array}{l}\text { Impaired } \\
\text { sition }\end{array}$} & \multirow{2}{*}{ Present } & Count in & 16 & 3 & 19 & \multirow{6}{*}{0.001} \\
\hline & & $\%$ of Total & $16.0 \%$ & $3.0 \%$ & $19.0 \%$ & \\
\hline & Absent & Count in & 34 & 47 & 81 & \\
\hline & & $\%$ of Total & $34.0 \%$ & $47.0 \%$ & $81.0 \%$ & \\
\hline \multirow{2}{*}{\multicolumn{2}{|c|}{ Total }} & Count & 50 & 50 & 100 & \\
\hline & & $\%$ of Total & $50.0 \%$ & $50.0 \%$ & $100.0 \%$ & \\
\hline
\end{tabular}

Table 7 represents the association between the serum uric acid with orthostatic hypotension and this found to be serum uric acid level has no correlation with orthostatic hypotension. 
Study Of Impact Of Serum Uric Acid In Type 2 Diabetic Patients And Its Relationship....

Table No 7

Serum uric acid level in the patients with Orthostatic hypotension

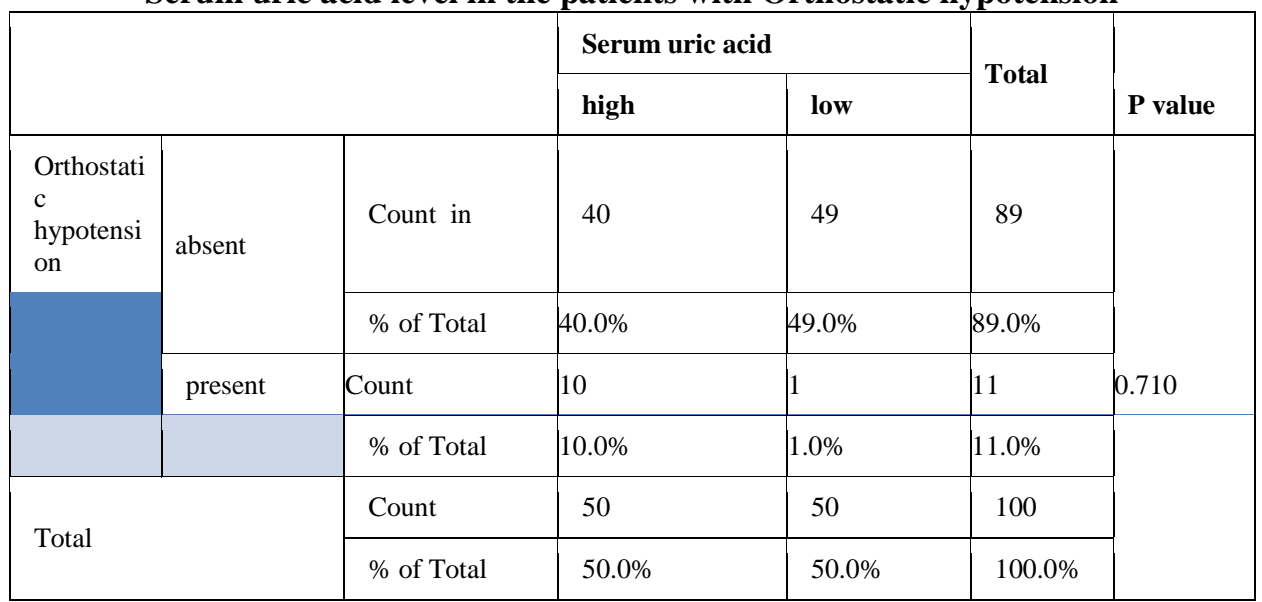

Table 8 represents the association between the serum uric acid and cerebrovascular accident patients. Based on our study we observed that patients who had cerebrovascular accident showed increased serum uric acid levels.

Table No 8

Serum uric acid level in the patients with Stroke

\begin{tabular}{|c|c|c|c|c|c|c|}
\hline & & & \multicolumn{2}{|c|}{ Serum uric acid } & \multirow{2}{*}{ Total } & \multirow[b]{2}{*}{$P$ value } \\
\hline & & & high & low & & \\
\hline \multirow[t]{4}{*}{ stroke } & \multirow{2}{*}{ yes } & Count & 48 & 19 & 67 & \multirow{6}{*}{0.001} \\
\hline & & $\%$ of Total & $48.0 \%$ & $19.0 \%$ & $67.0 \%$ & \\
\hline & no & Count & 2 & 31 & 33 & \\
\hline & & $\%$ of Total & $2.0 \%$ & $31.0 \%$ & $33.0 \%$ & \\
\hline \multirow{2}{*}{\multicolumn{2}{|c|}{ Total }} & Count & 50 & 50 & 100 & \\
\hline & & $\%$ of Total & $50.0 \%$ & $50.0 \%$ & $100.0 \%$ & \\
\hline
\end{tabular}

Table 9 showed patient with DKA and their serum uric acid value is not significant. From this we observed that there is no association between serum acid and development of DKA.

Table No.9

Serum uric acid level in individuals in association with diabetic ketoacidosis

\begin{tabular}{|c|c|c|c|c|c|c|}
\hline & & & Serum & acid & & \\
\hline & & & high & low & & $P$ value \\
\hline $\begin{array}{l}\text { Acetone } \\
\text { positive }\end{array}$ & hront & Count & 32 & 41 & 73 & \\
\hline & & $\%$ of Total & $32.0 \%$ & $41.0 \%$ & $73.0 \%$ & \\
\hline & present & Count & 18 & 9 & 27 & 0.071 \\
\hline & & $\%$ of Total & $18.0 \%$ & $9.0 \%$ & $27.0 \%$ & \\
\hline & & Count & 50 & 50 & 100 & \\
\hline & & $\%$ of Total & $50.0 \%$ & $50.0 \%$ & $100.0 \%$ & \\
\hline
\end{tabular}




\section{Discussion}

Among the 100 patients selected for our study, 50 patients had elevated serum Uric acid levels and the remaining 50 patients had normal or less than normal serum uric acid levels. In our study group all the patients underwent complete clinical examination and relevant laboratory and radiological investigations. After the detailed evaluation of the results of the study it was observed that the elevated levels of serum uric acid is associated with higher incidence of complications ${ }^{2}$ in the patients in our study group. Both microvascular and macrovascular complications are found to have been increased in diabetic patients ${ }^{5}$ with hyperuricaemia.In our study group, we observed that astrong associationof elevated uric acid levels with microvascular involvement of Kidneys ${ }^{6,3}$ Fundus, peripheral nerve and macrovascular involvement of coronary artery and cerebral vessels. The parameters that had an insignicant $\mathrm{P}$ value and hence lack of association between elevated uric acid are Orthostatic hypertension and Diabetic ketoacidosis.

\section{Summary:}

In this cross sectional study, out of the 100 patients involved in the study, 50 had elevated serum uric acid levels. On further analysis with the parameters used to access the patients, it was found that majority of those patients had significant association with development of complications and elevated serum uric acid levels. Except for Diabetic Ketoacidosis and Orthostatic Hypertension whose association with Hyperuricaemia was found to be insignificant other parameters had significant association with Hyperuricaemia.

\section{Conclusion}

In this study we conclude that elevated serum uric acid levels have positive correlation with both microvascular and macrovascular complications of diabetes mellitus.Orthostatic hypotension and diabetic ketoacidosis are not related to levels of serum uric acid.On the basis of the observations made on this study, frequent monitoring of serum uric acid levels can be very helpful in assessing the complications of the diabetes mellitus.

\section{References}

[1]. Liese AD, Hense HW, Lo“wel H, Döring A, Tietze M, Keil U. Association of serum uric acid with all-cause and cardiovascular disease mortality and incident myocardial infarction in the MONICA-Augsburg cohort: World Health Organization Monitoring Trends and Determinants in Cardiovascular Diseases. Epidemiology 1999; 10:391-397

[2]. Kanellis J, Kang DH. Uric acid as a mediator of endothelial dysfunction, inflammation, and vascular disease. SeminNephrol 2005;25:39-42

[3]. Fukui M, Tanaka M, Shiraishi E, Harusato I, Hosoda H, Asano M, Kadono M, Hasegawa G, Yoshikawa T, Nakamura N. Serum uric acid is associated with microalbuminuria and subclinical atherosclerosis in men with type 2 diabetes mellitus. Metabolism 2008;57:625-629

[4]. Chen JH, Chuang SY, Chen HJ, Yeh WT, Pan WH. Serum uric acid level as an independent risk factor for all-cause, cardiovascular, and ischemic stroke mortality: a Chinese cohort study. Arthritis Rheum 2009;61:225-232

[5]. Saggiani F, Pilati S, Targher G, Branzi P, Muggeo M, Bonora E. Serum uric acid related factors in 500 hospitalized subjects. Metabolism 1996;45:1557-1561

[6]. M. Chonchol, M. G. Shlipak, R. Katz et al., "Relationship of uric acid with progression of kidney disease," American Journal of Kidney Diseases, vol. 50, no. 2, pp. 239-247, 2007

[7]. Papanas N, Demetriou M, Katsiki N, et al. Increased Serum Levels of Uric Acid Are Associated with Sudomotor Dysfunction in Subjects with Type 2 Diabetes Mellitus. Exp Diabetes Res. 2011:1-5.

[8]. Skljarevski V, Malik RA. Clinical Diagnosis of Diabetic Neuropathy . In: Veves A, Malik RA, editors. Diabetic Neuropathy. Totowa, New Jersey: Humana Press; 2007. pp. 277-8.

[9]. Feldman T, Weitzman S, Biedner B. Retinopathy and serum uric acid in diabetics. Harefuah. 1995;128:681-3.

[10]. Lehto S, Niskanen L, Rönnemaa T, Laakso M. Serum uric acid is a strong predictor of stroke in patients with noninsulin dependent diabetes mellitus. Stroke. 1998;29:635-9. 